\title{
Hematological and Biochemical Alterations at Different Stages in Cattle Affected with Foot and Mouth Disease in Bangladesh
}

\author{
Md. Ashraf Zaman Faruk ${ }^{1 *}$, Shonkor Kumar Das ${ }^{1}$, Md. Abdul Awal ${ }^{1}$ and Dolan Das ${ }^{2}$ \\ ${ }^{1}$ Department of Anatomy and Histology, Bangladesh Agricultural University, Mymensingh-2202, Bangladesh \\ ${ }^{2}$ Department of Pharmacology, Bangladesh Agricultural University, Mymensingh-2202, Bangladesh
}

*Corresponding author: Md. Ashraf Zaman Faruk, Department of Anatomy and Histology, Bangladesh Agricultural University,

Mymensingh-2202, Bangladesh

\section{ARTICLE INFO}

Received: 慧 July 01, 2021

Published: 畿 July 14, 2021

Citation: Md. Ashraf Zaman Faruk, Shonkor Kumar Das, Abdul Awal, Dolan Das. Hematological and Biochemical Alterations at Different Stages in Cattle Affected with Foot and Mouth Disease in Bangladesh. Biomed J Sci \& Tech Res 37(2)-2021. BJSTR. MS.ID.005962.

Keywords: Foot and Mouth Disease; Days Post Infection; Hematology; Biochemical

\begin{abstract}
The aim of this study was carried out to evaluate the possible variation of hematological and biochemical profile in naturally infected cattle with Foot and Mouth Disease during the disease outbreak in 2016. For this purpose, a total number of 20 cattle over 1 year of age were used in this experiment. Of these 15 cattle showed characteristics clinical signs of FMD that exposed from 1 to $14^{\text {th }}$ days of post infection (DPI) and the remaining 5 cattle were clinically healthy and used as controls. Blood samples were used to establish total RBC, Hb, PCV, MCH and total MCV. Serum's samples were also collected and used to establish the total protein, albumin, globulin, blood urea nitrogen (BUN), cholesterol, calcium, phosphorus and glucose. The mean values of red blood cells (RBCs), and hemoglobin $(\mathrm{Hb})$ were decreased significantly $(\mathrm{p} \leq 0.01)$, on the other hand MCV value was increased significantly $(\mathrm{p} \leq 0.05)$ in FMD affected cattle in comparison to their healthy group. The serum biochemical constituents were representing a significant reduction in the average value of total protein, albumin, globulin, blood urea nitrogen, cholesterol and significant production $(\mathrm{p} \leq 0.01)$ of phosphorus and glucose in cattle affected with FMD. Therefore, comparative study among the hematological and biochemical data concluded that, FMD causes significant decrease of RBC count, Hb, total protein, albumin, globulin, blood urea nitrogen, cholesterol and significant increase of MCV and glucose and phosphorus.
\end{abstract}

\section{Introduction}

Foot and mouth disease (FMD) is one of the most devastating disease of farm animals in the world that can destroy food supplies and farmer's livelihoods almost overnight of the wide number of cloven-hoofed animals include cattle, buffalo, pigs, sheep and goat [1]. The disease Foot and mouth disease (FMD) is generally characterized by the rapid appearance of high body temperature, respiratory and pulse rate following by the formation of vesicles on the tongue epithelium and skin particularly on the inter-digital space epithelium of the foot [2,3]. Even after recovery from the acute infection, most animals act as a carrier for each serotypes of the virus and the agent can be isolated from their esophagus and throat fluid after 2-3 years of post-infection [4-6] with a moderate raised values $(p \leq 0.05)$ were recorded in rectal temperature, respiratory and pulse rate, where highest values were during 3 to 7 days of post infection which subsequently reduced after passing the days of infection [7]. Although FMD does not cause high mortality in adult animals, the disease has debilitating effects, including weight loss, decrease in milk production, reproductive failures and loss of draught power resulting in reduced productivity. Mortality, however, can be high in young animals up to $100 \%$, wherein the virus causes myocardial degeneration, known as Tiger Heart disease [8]. It is estimated that $25 \%$ productivity of individual recovered animals are lost due to FMD [9]. It causes low 
production for the affected countries; severe restrictions are placed on international trade of animal and animal products (meat, milk, hide and butter) due to its transboundary nature of transmission [10]. Studies conducted by Bangladesh Livestock Research Institute (BLRI) revealed that during an outbreak the morbidity, in cattle to be around $36 \%$, in buffaloes $23 \%$, in sheep and goat $5 \%$ and case fatality rate, especially in calves, has been found to be about $51 \%$ in outbreak area (www.blri.gov.bd). Annual losses due to the outbreak of FMD in Bangladesh have been estimated to be US\$10.92 million per year [11].

The causal agent, FMD virus belongs to the genus Aphthovirus, under the family Picornaviridae, of which there are seven immunologically distinct serotypes; O, A, C, South African Territories (SAT)-1, SAT-2, SAT- 3 and Asia-1, and at least 65 subtypes have been identified [10]. Chowdhury et al. [12] reported that Foot and mouth disease (FMD) is endemic both in Bangladesh and its neighboring countries like India, Nepal, Bhutan and Myanmar. In Bangladesh during 2007 to 2008, Serotypes A, O, C and Asia-1 have been identified where A, $O$ and Asia-1are very common, while type $C$ has been identified scarcely. The pathogenicity in case of FMDV type $\mathrm{O}$ is always severer than type A, C and Asia-1. However, recently FMDV types A and Asia-1 are also found as severe as FMDV type 0 [13]. The disease is often transmitted from the infected to the apparently healthy susceptible animals through air or direct contact and disease outbreak is high in the winter (DecemberFebruary) and in monsoon (June-September) of a year in tropical and subtropical country of the world [14-16]. The outbreak of this disease has become a regular event throughout the country in every year, while the exact reason for this frequency is not very clear, but it is assumed that the outbreak of the disease may be due to new introduction of mutant viruses. Moreover, a significant number of cattle and buffaloes have been entering from India to Bangladesh in every year either through proper or improper channels which directly or indirectly serves as a source of new virus introduction [17].

Laboratory based works on FMD specially it's isolation; identification and vaccine development were carried out in Bangladesh as well as only few studies reported on the hematological and biochemical alterations at different stages of bovine FMD. Moreover, almost no reports are available on the hematological and biochemical changes at different stages in naturally infected cattle with FMD in Bangladesh. Therefore, the aim of this present research was to determine the possible alterations in hematological and biochemical parameters in cattle with Foot and Mouth Disease at primary, advanced and recovery stages in Bangladesh.

\section{Materials and Methods}

This research was performed in the laboratory of the Department of Anatomy \& Histology, Bangladesh Agricultural
University, Mymensingh-2202 during the outbreak report from June to November in 2016. Clinically FMD affected cattle and some healthy cattle (for control group) over 1 year of age were selected for the evaluation of effective hematological and biochemical changes at different outbreak areas of Rajshahi, Mymensingh and Bandarbon each of these districts shares common boundaries with the neighboring country India (Figure 1).

\section{A. Study Design}

A total number of 20 cattle were used in this study, of these 15 cattle showed characteristic clinical sign of FMD. The remaining 5 cattle were apparently healthy and selected as a control group. Peripheral blood samples, 20 samples each were collected directly from the jugular vein with the help of $10 \mathrm{ml}$ sterile syringe and put into blood collecting vial (Vacuum Tube, K3EDTA, REF Ko3oEDE) containing anticoagulant EDTA (ethylene diamine tetra acetic acid at $2 \mathrm{mg} / \mathrm{ml}$ ) to investigate the WBC, RBC, Hb. conc., PCV, MCV and MCH for hematological study (Figure 2). Another 20 samples from the jugular vein were collected and put into blood collecting vial (Vacuum Tube, K3EDTA, REF Ko3oEDE) without anticoagulant for total serum protein, albumin, globulin, BUN, calcium, glucose, phosphorus and cholesterol test for biochemical study. These collected samples were divided into four groups:

a) Group A (Control group): Group A is control group with normal physiological condition and no clinical findings.

b) Group B (Primary stage): Group B is referred to as primary stage group where animal are affected with FMD disease of $1^{\text {st }}$ to $2^{\text {nd }}$ days of post infections.

c) Group C (Advanced stage): Group C is referred to as advanced stage group where animal are affected with FMD disease of $3^{\text {rd }}$ to $7^{\text {th }}$ days of post infections.

d) Group D (Recovery stage): Group D is referred to as recovery stage group where animal are affected with FMD disease of $8^{\text {th }}$ to $14^{\text {th }}$ days of post infections.

\section{B. Hematological Study}

The anticoagulant added samples were examined for hematological study of red blood cells count (RBCs, 106/ $\mu \mathrm{l}$ ), white blood cells count (WBCs, 103/ $\mu \mathrm{l})$, hemoglobin $(\mathrm{Hb}, \mathrm{g} / \mathrm{dl})$, packed cell volume (PCV\%) as per method described by Mohan et al. [18]. The mean corpuscular volume (MCV,fl), and the mean corpuscular hemoglobin (MCH, pg) were calculated as mentioned by Gökçe et al. [19].

\section{Biochemical Study}

Through the non-anticoagulant added samples, the concentration of different serum biochemical constituents such as the average value of total protein, albumin, globulin, blood urea 
nitrogen (BUN), cholesterol, calcium, phosphorus and glucose were examined by standard method.

\section{Statistical Analysis}

All the collected data were analyzed by using IBM SPSS Statistics (version 20) software and revealed the results in necessary forms. Statistical analysis was performed using one-way analysis of variance (ANOVA) followed by post hoc Duncan's test. Results were expressed as mean \pm standard error (S.E). Differences between groups were considered significant at $\mathrm{p}<0.01$ and $\mathrm{p}<0.05$ level.

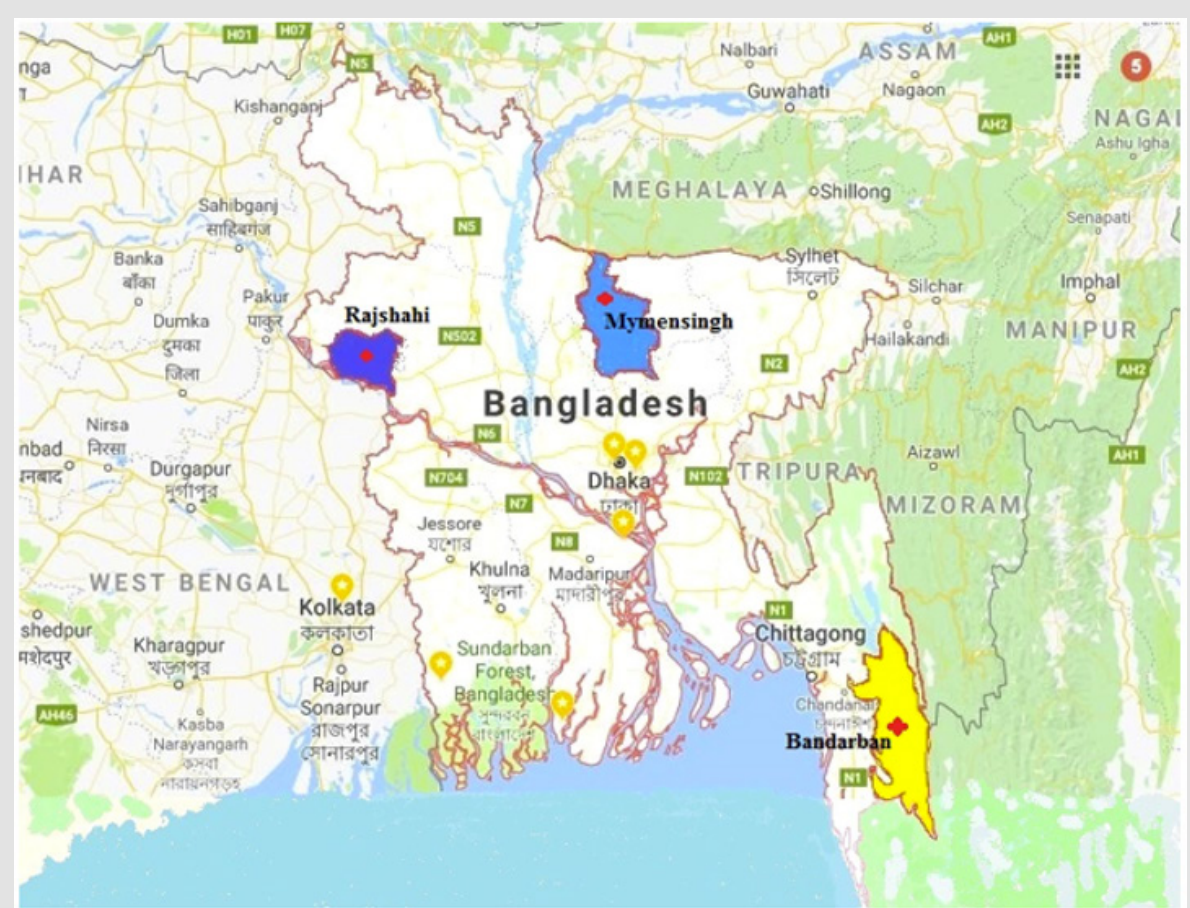

Figure 1: Location of study area inside Bangladesh. Rajshahi, Mymensingh and Bandanban districts share common boundaries with the neighboring country India.

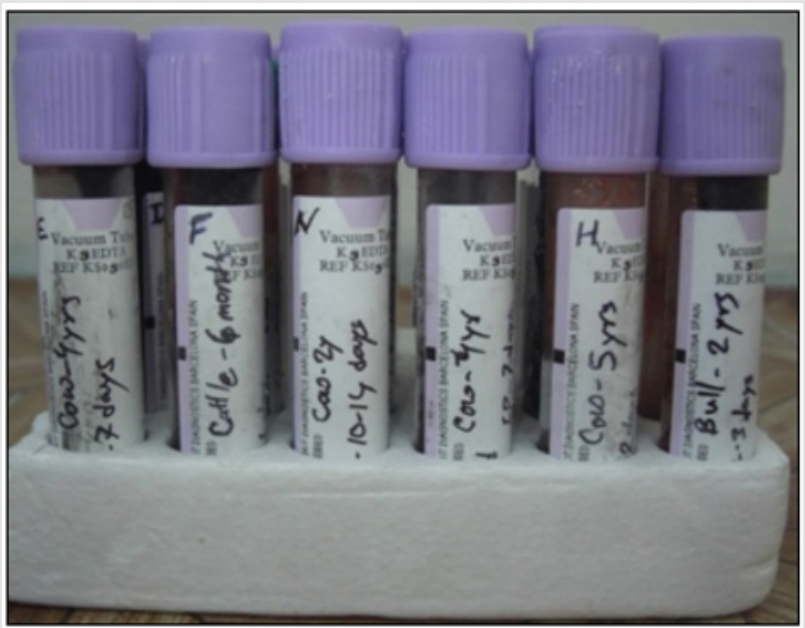

Figure 2: Collected blood sample for hematological and biochemical examination.

\section{Results and Discussion}

\section{E. Hematological Study}

The concentration of different hematological indices (mean \pm SE values) are presented in the Table 1. In this present study, the total number of red blood cells (RBC) count in foot-and-mouth disease cattle at primary, advanced, recovery stage groups (Group B, Group C, Group D) and apparently healthy animals (Group A) were $4.98 \pm 1.48 \times 10^{6} / \mu \mathrm{l}, 4.60 \pm 0.48^{* *} \times 10^{6} / \mu \mathrm{l}, 5.14 \pm 1.36 \times 10^{6} /$ $\mu \mathrm{l}$ and $5.5 \pm 0.29 \times 10^{6} / \mu \mathrm{l}$ respectively. Similarly, the hemoglobin concentration were $8.85 \pm 1.25 \mathrm{~g} / \mathrm{dl}, 8.32 \pm 0.78^{* *} \mathrm{~g} / \mathrm{dl}, 9.25 \pm 2.02$ $\mathrm{g} / \mathrm{dl}$ and $9.57 \pm 1.08 \mathrm{~g} / \mathrm{dl}$ at the primary, advanced, recovery stage 
groups (Group B, Group C, Group D) and control group (Group A) respectively Table 1 . Statistical analysis revealed that the RBCs count and $\mathrm{Hb}$ conc. specially at the advanced stage (group C) was significantly $(p<0.01)$ lower than the other groups that might be due to reduction of the process of erythropoesis and hemolysis [20]. Similar findings are also observed by different workers in FMD infection [18,19,21]. On the other hand, FMD infected animals showed significant production of mean corpuscular volume (MCV) $(\mathrm{p} \leq 0.05)$ at advanced $(64.27 \pm 3.94 * \mathrm{fl})$ stage group as compared to the primary $(60.65 \pm 2.67 \mathrm{fl})$ stage, recovery $(56.20 \pm 2.48 \mathrm{fl})$ stage and control (51.80 $\pm 2.86 \mathrm{fl})$ group Table 1 same findings are recorded by Gokce et al. [19], Ghanem et al. [21], Mohapatra et al. [22], Krupakaran et al. [23] and Gattani et al. [24]. These results could be attributed to endocrinopathy is reported previously by Radostits et al. [20].

Table 1: Hematological parameters (mean \pm SE values) in FMD at primary, advanced, recovered stage group and control group with normal range.

\begin{tabular}{|c|c|c|c|c|c|c|}
\hline Parameters & Primary Stage & Advanced Stage & Recovery Stage & Control Stage & Normal Range & Level Of Significant \\
\hline $\mathrm{RBCs}\left(\mathrm{x} 10^{6} / \mu \mathrm{l}\right)$ & $4.98 \pm 1.48$ & $4.60 \pm 0.48$ & $5.14 \pm 1.36$ & $5.5 \pm 0.29$ & $5-10$ & $*$ \\
\hline $\mathrm{WBCs}\left(\mathrm{x} 10^{3} / \mu \mathrm{l}\right)$ & $6.35 \pm 0.75$ & $6.55 \pm 0.07$ & $6.73 \pm 0.85$ & $6.84 \pm 0.37$ & $4-11$ & NS \\
\hline $\mathrm{Hb}(\mathrm{g} / \mathrm{dl})$ & $8.85 \pm 1.25$ & $8.32 \pm 0.78$ & $9.25 \pm 2.02$ & $9.57 \pm 1.08$ & $8-15$ & $* *$ \\
\hline $\mathrm{PCV}(\%)$ & $29.95 \pm 2.50$ & $30.30 \pm 3.65$ & $31.97 \pm 1.87$ & $32.97 \pm 2.07$ & $24-46$ & NS \\
\hline $\mathrm{MCH}(\mathrm{pg})$ & $19.53 \pm 3.79$ & $20.40 \pm 3.94$ & $18.33 \pm 2.49$ & $18.69 \pm 0.95$ & $14.4-18.6$ & NS \\
\hline $\mathrm{MCV}(\mathrm{fl})$ & $60.65 \pm 2.67$ & $64.27 \pm 3.94$ & $56.20 \pm 2.48$ & $51.80 \pm 2.86$ & $40-60$ & $*$ \\
\hline
\end{tabular}

Results are Mean \pm SE (Standard Error) in each group. One-way analysis of variance (ANOVA) followed by post hoc Duncan's test was performed as the test of significance. The difference was considered to be significant when ${ }^{* *} p<0.01$, ${ }^{*} p<0.05$ compared to FMD control group.

\section{NS $=$ Not significant}

Besides these, the total white blood cells (WBC) count, the mean value of packed cell volume (PCV), and the value of mean corpuscular hemoglobin (MCH) in FMD affected animals at primary, advanced, recovery stage groups did not show any significant alteration along with the control group and our findings also are corroborated with the observation made by Mohan et al. [18], Gokce et al. [19] and Al-Rukibat et al. [25].

\section{F. Biochemical Study}

The concentration of different biochemical indices (mean \pm SE values) are presented in the Table 2. This study demonstrated that the average value of total serum protein were $6.20 \pm 0.65 \mathrm{~g} / \mathrm{dl}$, $4.32 \pm 0.17^{* *} \mathrm{~g} / \mathrm{dl}, 5.95 \pm 0.57 \mathrm{~g} / \mathrm{dl}$ and $7.07 \pm 0.72 \mathrm{~g} / \mathrm{dl}$ and albumin concentration were $2.99 \pm 0.23 \mathrm{~g} / \mathrm{dl}, 2.17 \pm 0.11^{* *} \mathrm{~g} / \mathrm{dl}, 3.96 \pm 0.18 \mathrm{~g} /$ $\mathrm{dl}$ and $4.65 \pm 0.18 \mathrm{~g} / \mathrm{dl}$ in FMD at the primary, advanced, recovery stage groups and control group respectively Table 2 . The total serum protein and albumin concentration were significantly $(\mathrm{p}<0.01)$ decreased at advanced stage rather than the other groups. Roussel et al. [26] reports that the decrease level of total protein concentration is associated with hepatic and renal damage, starvation, enteropathies that resulting in protein loss and the presence of infection or any lesion in the body is also recorded by Meyer etal. [27]. which was inconsonance with our observation. Low albumin and protein concentrations may also be due to alterations in pancreatic $\beta$-cell functions that might have developed during the clinical course of FMD is reported by Barboni et al. [28]. As well as, serum globulin concentration showed a significant decrease $(\mathrm{p}<0.05)$ at the advanced stage as compared to primary, recovery stage groups and control group. The serum globulin concentration at the primary, advanced, recovery stage groups and control group were $2.40 \pm 0.08 \mathrm{~g} / \mathrm{dl}, 2.14 \pm 0.14^{*} \mathrm{~g} / \mathrm{dl}, 2.35 \pm 0.30 \mathrm{~g} / \mathrm{dl}$ and $2.78 \pm 0.30$ $\mathrm{g} / \mathrm{dl}$ respectively Table 2 , that might be due to hypoglobulinemia in the affected animals, coming in parallel with mention by Gokce et al. [19], Ghanem et al. [21], Mohapatra et al. [22], Krupakaran et al. [23] and Gattani et al. [24].

Table 2: Biochemical parameters (mean \pm SE values) in FMD at primary, advanced, recovered stage group and control group with normal range.

\begin{tabular}{|c|c|c|c|c|c|c|}
\hline Parameters & Primary Stage & Advanced Stage & Recovery Stage & Control Stage & Normal Range & Level Of Significant \\
\hline Total Protein $(\mathrm{g} / \mathrm{dl})$ & $6.20 \pm 0.65$ & $4.32 \pm 0.17$ & $5.95 \pm 0.57$ & $7.07 \pm 0.72$ & $5.7-8.1$ & $* *$ \\
\hline Albumin(g/dl) & $2.99 \pm 0.23$ & $2.17 \pm 0.11$ & $3.96 \pm 0.18$ & $4.65 \pm 0.18$ & $2.1-3.6$ & $* *$ \\
\hline Globulin(g/dl) & $2.40 \pm 0.08$ & $2.14 \pm 0.14$ & $2.35 \pm 0.30$ & $2.78 \pm 0.30$ & $2.2-4.2$ & $*$ \\
\hline BUN (mg/dl) & $18.44 \pm 0.34$ & $16.92 \pm 0.44$ & $18.94 \pm 0.33$ & $20.19 \pm 0.68$ & $18-28$ & $* *$ \\
\hline Cholesterol(mg/dl) & $170.51 \pm 5.27$ & $156.45 \pm 3.64$ & $184.33 \pm 4.97$ & $192.69 \pm 5.77$ & $65-220$ & $*$ \\
\hline Calcium(g/dl) & $7.80 \pm 0.80$ & $7.67 \pm 0.78$ & $8.98 \pm 0.85$ & $9.18 \pm 0.85$ & $9.7-12.4$ & NS \\
\hline
\end{tabular}




\begin{tabular}{|c|c|c|c|c|c|c|}
\hline Phosphorus(g/dl) & $6.98 \pm 0.37$ & $8.55 \pm 0.57$ & $5.7 \pm 0.24$ & $5.3 \pm 0.86$ & $5.6-6.5$ & $*$ \\
\hline Glucose(g/dl) & $67.39 \pm 4.07$ & $73.94 \pm 2.17$ & $52.91 \pm 3.27$ & $51.28 \pm 3.67$ & $45-75$ & $* *$ \\
\hline
\end{tabular}

Results are Mean \pm SE (Standard Error) in each group. One-way analysis of variance (ANOVA) followed by post hoc Duncan's test was performed as the test of significance. The difference was considered to be significant when ${ }^{* *} \mathrm{p}<0.01$, ${ }^{*} \mathrm{p}<0.05$ compared to FMD control group.

NS $=$ Not significant

Though the blood urea nitrogen (BUN) concentrations were decreased significantly $(\mathrm{p}<0.01)$ at the advanced stage group $\left(18.44 \pm 0.34^{* *} \mathrm{mg} / \mathrm{dl}\right)$ as compared with the primary $(16.92 \pm 0.44$ $\mathrm{mg} / \mathrm{dl})$, recovery $(18.94 \pm 0.33 \mathrm{mg} / \mathrm{dl})$ and control group $(20.19 \pm 0.68 \mathrm{mg} / \mathrm{dl})$. It might be due to hypoproteinemia in the affected group. As well as the mean value of cholesterol in FMD at the primary, advanced, recovery stage groups and control group were $170.51 \pm 5.27 \mathrm{mg} / \mathrm{dl}, 156.45 \pm 3.64^{* *} \mathrm{mg} / \mathrm{dl}, 184.33 \pm 4.97 \mathrm{mg} / \mathrm{dl}$ and 192.69 \pm 5.77 respectively Table 2 , while the normal range is 65 $220 \mathrm{mg} / \mathrm{dl}$. This study was revealed a significant $(\mathrm{p}<0.01)$ reduction of cholesterol level at the advanced stage group (Group C) and may be due to dysfunction of pancreatic $\beta$-cell is suggested by Gokce et al. [19] and Ghanem et al. [21]. Nevertheless, the mean value of calcium level at the primary, affected, recovered stages and control group was reported very little significant which is also mentioned by Mohapatra et al. [22], Krupakaran et al. [23] and Gattani et al. [24]. This research also revealed a significant $(p<0.01)$ production of phosphorus (P) concentration between the affected and control groups. The mean value of phosphorus (P) in foot-and-mouth disease cattle at primary, advanced, recovery stage groups and control group were $6.98 \pm 0.37,8.55 \pm 0.57^{* *}, 5.7 \pm 0.24$ and $5.3 \pm 0.86$ $\mathrm{g} / \mathrm{dl}$ respectively. Hyperphosphatemia recorded in our result is also noted by Gokce et al. [19], Ghanem et al. [21], Mohapatra et al. [22], Krupakaran et al. [23] and Gattani et al. [24]. Similarly, Glucose concentration was significantly $(\mathrm{p}<0.01)$ increased at the advanced stage $\left(73.94 \pm 2.17^{* *} \mathrm{mg} / \mathrm{dl}\right)$ group in analogy with the primary $(67.39 \pm 4.07 \mathrm{mg} / \mathrm{dl})$, recovered $(52.91 \pm 3.27 \mathrm{mg} / \mathrm{dl})$ stage groups and control group (51.28 $\pm 3.67 \mathrm{mg} / \mathrm{dl})$ Table 2 . An increased concentration of glucose was well documented in cattle affected with FMD is recorded by Elitok et al. [29] and also a common finding in cattle affected by the stress in systemic disease is described by Gokce et al. [19], Paalberg et al. [30] and Yeotikar et al. [31].

\section{Conclusion}

From this present study, it can be concluded that the concentration of different hematological constituents revealed a significant reduction ( $\mathrm{p} \leq 0.01)$ of red blood cells $(\mathrm{RBC})$, hemoglobin $(\mathrm{Hb})$ and significant production $(\mathrm{p} \leq 0.05)$ of mean corpuscular volume (MCV) especially at the advanced stage (group B) rather than the control groups. Similarly, at $3^{\text {rd }}$ to $7^{\text {th }}$ days of post infection that is in advanced stage, the serum biochemical concentration of total protein, albumin, globulin, blood urea nitrogen, cholesterol are significantly decreased and significant increase $(\mathrm{p} \leq 0.01)$ of glucose and phosphorus in FMD affected animals in comparison to the other respective groups.

\section{Acknowledgment}

The author is deeply grateful to the Department of Anatomy and Histology for supporting this work and to the Department of Physiology, Bangladesh Agricultural University, Mymensingh-2202, for helping in the hematological and biochemical analysis. The author would like to thank KGF, BARC (Project ID: TF 12-L) for financial assistance to complete this research smoothly.

\section{Conflict of Interests}

The authors declare that they have no conflict of interest for the research, authorship, and/or publication of this article.

\section{Authors' Contribution}

MAZF designed the study, interpreted and analyzed the data, and drafted the manuscript. DS was involved in collection of data and also contributed in manuscript preparation. SKD and MAA took part in supervising the research and critical checking of this manuscript.

\section{References}

1. Bronsvoort BM de C, Radford AD, Tanya VN, Nfon C, Kitching RP, et al. (2004a) Molecular epidemiology of foot and mouth disease viruses in the Adamawa Province of Cameroon. J Clin Microbiol 42(5): 2186-2196.

2. Sahan MS (1962) The virus of foot-and-mouth disease. Ann N Y Acad Sci 101: 444-454.

3. Bachrach HL (1968) Foot and Mouth Disease. Ann Rev Microbiol 22: 201-244.

4. Sutmollet P, Gaggero A (1965) Foot and mouth disease carriers. Vet Rec 77(33): 968-969.

5. Burrow R (1966) Studies on the carrier state cattle exposed to foot-andmouth disease virus. J. Hyg 64(1): 81-90.

6. Augé de Mello P, Honigman MH, Fernandes MV, Gomes I (1970) Further information on the survival of modified of foot-and-mouth disease virus in cattle. Bull. Off. Int. Epizoot 73(5): 489-505.

7. Faruk MAZ, Das SK (2021) Comparative Histomorphological Changes of Bovine Foot and Mouth Disease (FMD) at different Clinical Stages in Bangladesh. Int J Curr Microbiol App Sci 10(06): 29-39.

8. Gleeson LJ, Bauer K, Aidaros HA (2002) A review of the status of FMD in Southeast Asia and approach to control and eradication. Science and technology review 21(3): 465-475.

9. Russel PH, Edington N (1985) Veterinary Viruses. The Burlington press (Cambridge) Ltd. Foxton, Cambridge: 326-340. 
10. OIE (2009) Principal of Veterinary Vaccine Production. In: Manual of Diagnostic Test and Vaccines for Terrestrial Animals. Version adopted May 2006 Chapter 1.1.7.

11. Islam MR (2011) Regional study on economic impact of transboundary animal diseases. Country status: Bangladesh. SAARC Agriculture Center Dhaka.

12. Chowdhury SMZH, Rahman MF, Rahman MB, Rahman MM (1994b) Strain of FMD virus in different district in Bangladesh. Pak. Vet. J 14: 8991.

13. Zinnah (2008) Development of molecular methods for simultaneous detection of food and mouth disease viruses serotypes prevalent in Bangladesh. Thesis submitted in the Department of Microbiology and Hygiene, BAU Mymensingh, Bangladesh.

14. Kiryukin RA, Pasechnikov LN (1966) Isolation of foot-and-mouth disease virus from air exalted by infected animals. Vet. Mosc 43(6): 30-31.

15. Hafez SM, Farag MA, Al-Sukyran AM (1994) The impacts of the living animal important on the epizootiology of foot-and-mouth disease in Saudia Arabia. Deuts. Tierarz. Wochen 101(10): 397-402.

16. Gomes L, Rahmalho AK, Auge-de-MeHo P (1997) Infectivity assay of foot and mouth disease virus: contact transmission between cattle and buffalo (bubalas bubalis) in the early stage of infection. Vet. Rec 140(2): 43-47.

17. Kamaruddin KM, Pandit KK (1988) Pattern of Foot and mouth disease virus infection in cattle of Bangladesh. Bangladesh Veterinary Journal 5: 54-58.

18. Mohan MS, Gajendragad MR, Gopalakrishna S, Singh N (2008) Comparative study of experimental Foot-and-Mouth Disease in cattle (Bos indicus) and buffaloes (Bubalis bubalus); Vet. Res. Common 32(6): 481-489.

19. Gökce G, Gökce Hİ, Güneș V, Erdoğan HM, Çitil M, et al. (2004) Alterations in Some Haematological and Biochemical Parameters in Cattle Suffering from Foot-and-Mouth Disease. Turk. J. Vet. Anim. Sci 28(4): 723-727.

20. Radostits OM, Gay CC, Hinchcliff KW, Constable PD (2007) Veterinary Medicine: A textbook of the diseases of cattle, horses, sheep, pigs and goats (10 ${ }^{\text {th }}$ Edition). Elsevier, London: 399-438.

\section{ISSN: 2574-1241}

DOI: 10.26717/BJSTR.2021.37.005962

Md. Ashraf Zaman Faruk. Biomed J Sci \& Tech Res

This work is licensed under Creative

Commons Attribution 4.0 License

Submission Link: https://biomedres.us/submit-manuscript.php
21. Ghanem MM, Abdel-Hamid OM (2010) Clinical, haematological and biochemical alterations in heat intolerance (panting) syndrome in Egyption cattle following natural foot-and-mouth disease (FMD). Tropical Animal Health and Production 42(6): 1167-1173.

22. Mohapatra APK, Kundum AK, Bisoi PC, Prusty BM (2005) Haematological and biochemical changes in crossbred cattle affected with foot and mouth disease. Indian Veterinary Journal 82(2): 141-144.

23. Krupakaran RP, Porcheziyan T, Sivseeian S (2009) Biochemical and haematological profile of foot and mouth disease affected crossbred cows in Karur district of Tami Nadu. Veterinary Practitioner 10(1): $37-$ 38.

24. Gattani A, Gupta KK, Joshi G, Gupta SR (2011) Metabolic profile of foot and mouth disease stressed sheep in semi-arid region. Journal of Stress Physiology \& Biochemistry 7(2): 149-153.

25. Al-Rukibat RK, Hananeh W, Athamneh H (2015) Comparative study of foot and mouth disease in apparently healthy Awassi sheep using different diagnostic tests in Jordan. Vet Sci Dev 5(1): 5633.

26. Roussel AJ, Whitney MS, Cole DJ (1997) Interpreting a bovine serum chemistry profile: Part 1. Vet. Med 92(6): 553-558.

27. Meyer DJ, Harvey JW (1998) Veterinary Laboratory Medicine: Interpreting and Diagnosis Saundres. Philadelphia. USA.

28. Barboni E, Mannocchio I, Asdrubahi G (1966) Observation on diabetes mellitus associated with experimental foot and mouth disease in cattle. Vet Ital 17: 339-368.

29. Elitok B, Ballkçl E, Keçeci H, Yllmaz K (1999) Serum creatinine phosphokinase (CPK), lactate dehydrogenase (LDH), aspartate aminotransferase (AST), activities, glucose levels and ECG findings in stemmed cattle. Kafkas Univ vet fac Journal 5: 161-166.

30. Paalberg PL, Lee JG, Seitzinger AH (2002) Potential revenue impact of an outbreak of foot and mouth disease in the United States. J Am Vet Med Assoc 220(7): 988-992.

31. Yeotikar PV, Bapat ST, Bilolikar SC, Kulkarni SS (2003) Metabolic profile of healthy cattle and cattle affected by foot-and-mouth disease. Veterinary Record 153(1): 19-20.

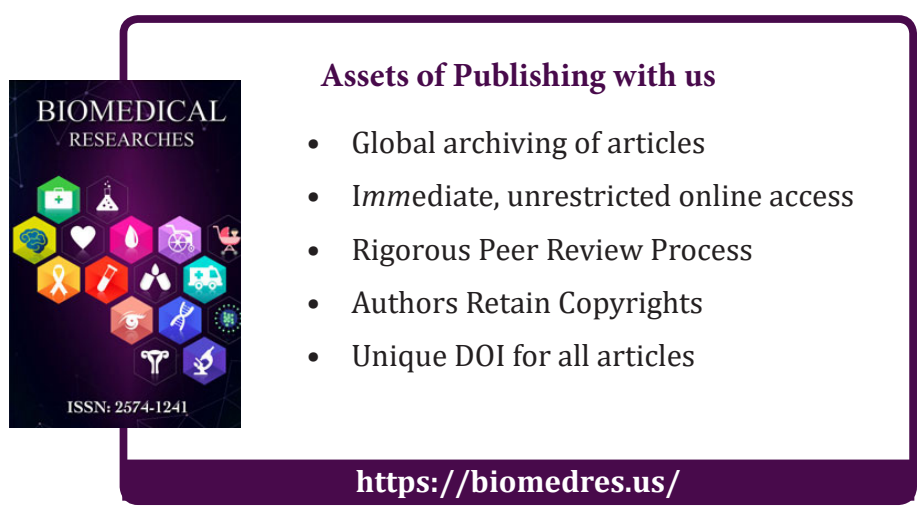

